\title{
Tomasz Twardziłowski
}

Independent scholar

ORCID: 0000-0002-5510-8487

\section{The Command to Rule over the Creation (Gen 1:26-28) in the Ecological Hermeneutics of the Bible ${ }^{1}$}

\begin{abstract}
In the discussions on the possible religious background of the current ecological crisis, the biblical text of Genesis 1:26-28 is the passage most often quoted by all sides of the debate. While for some it is an incentive to unlimited exploitation, and the resultant degradation of the natural environment, for others it carries a positive ecological message and a call for responsible care of the created world. Due to this ambiguity in interpretations, this article attempts to resolve whether the biblical text itself is problematic, and requires correction, or whether it is ecologically adequate, and it is the interpretations that have been thus far insufficient. Each of the three main currents of the ecological hermeneutics of the Bible (apologetic, radical, and neoorthodox) offers its own specific answer to this question.
\end{abstract}

Keywords: ecology, ecological hermeneutics of the Bible, creation, Gen 1:26-28

\section{Introduction} The fragment of Gen 1:26-28 is known primarily as the story
of the creation of man in the image of God (Imago Dei). ${ }^{2}$

${ }^{1}$ This article is a revised and updated version of the previous study published in Polish: Tomasz Twardziłowski, "Polecenie panowania nad stworzeniem (Rdz 1,26-28) w ekologicznej hermeneutyce Biblii," Collectanea Theologica 87 (2017) no. 1, 5-24. Translated from Polish by Lingua Lab.

2 The article presents the results of studies conducted as part of the research project:

"Ekologiczna hermeneutyka Biblii: cele, założenia, rezultaty, zastosowania" 
However, it also contains a divine command for people to reproduce and subdue the Earth. Due to the territorial spread of Christianity, this passage played an important role in shaping the culture almost all over the world. ${ }^{3}$ God's command to the first people and its interpretation in theology underpinned the charges against the Judeo-Christian worldview of causing or seriously contributing to the ecological crisis. Both opponents and supporters of environmentalism refer to this divine command. The position of theologians and biblical scholars is also far from unanimous in the ecological discussion. While some treat the words from the Book of Genesis as an imperative of responsible care for creation, understood as stewardship, others see the same words as giving man a mandate to freely exploit natural resources. This key issue was also recognised by Pope Francis, who in the encyclical Laudato si' postulated the need to read biblical texts in accordance with "proper hermeneutics," without specifying, however, what the latter should be. ${ }^{4}$ Therefore, it seems all the more appropriate to perform an in-depth scientific reflection on the understanding of the command

[Ecological Hermeneutics of the Bible: Goals, Guidelines, Results, Applications], carried out at the Cardinal Stefan Wyszyński University in Warsaw. The project was financed from the funds of the National Science Center granted on the basis of the decision no. DEC-2013/09/N/HS1/03628. The author devoted much attention to the discussed biblical fragment in his monographs: T. Twardziłowski, Ekologiczna hermeneutyka Biblii (Warszawa: 2015); idem, Ocalić stworzenie. Teoria i zastosowanie ekologicznej hermeneutyki Biblii (Warszawa: 2017) (see particularly chapter 3: "Polecenie panowania nad stworzeniem «Rdz 1,26-28»," 183-239).

3 Regarding the history of interpretation and impact of this passage, see P. Harrisson, "Subduing the Earth: Genesis 1, Early Modern Science, and the Exploitation of Nature," JR 79, no. 1 (1999): 86-109; G.P. Luttikhuizen, ed., The Creation of Man and Woman: Interpretations of the Biblical Narratives in Jewish and Christian Traditions (TBN 3) (Leiden, Boston, Köln: 2000); G.H. van Kooten, ed., Re-interpretations of Genesis I in the Context of Judaism, Ancient Philosophy, Christianity, and Modern Physics (TBN 8) (Leiden, Boston: 2005); J. Wöhrle, "Dominium terrae: Exegetische und religionsgeschichtliche Überlegungen zum Herrschaftsauftrag in Gen 1, 26-28," ZAW 121, no. 2 (2009): 171-88; B. Becking, S. Hennecke, eds., Out of Paradise: Eve and Adam and Their Interpreters (HBM 30) (Sheffield: 2011).

${ }^{4}$ See Francis, "Encyclical Laudato si ,', (May 24, 2015), no. 67; English translation, accessed September 30, 2020, http:/www.vatican.va/content/dam/francesco/pdf/ encyclicals/documents/papa-francesco_20150524_enciclica-laudato-si_en.pdf. 
given in Gen 1:26-28 and its impact on the way of thinking and actions of the recipients of the biblical message.

The article will outline the development of the ecological hermeneutics of the Bible, a certain novelty in biblical research. ${ }^{5}$ Furthermore, it will present the textual issues related to the analysed fragment, as well as the views and readings of Gen 1:26-28 in the three main currents of the ecological hermeneutics of the Bible: apologetic, radical, and neo-orthodox.

\section{Development of the Ecological Hermeneutics of the Bible}

The ecological movement, understood as the protection of the natural environment against degradation and excessive exploitation by people, developed on the rising tide of contestation movements at the turn of the 1960s, and 1970s. At the same time critical voices came to be heard directed to the Bible-based Christian worldview, indicating its responsibility for the environmental crisis. One of the first to present such charges was Lynn T. White Jr., whose thesis became a permanent point of reference for discussions about the responsibility of the Bible and Christianity for the ecological crisis. ${ }^{6}$ In his opinion, the Christian worldview, especially the conviction that man is made in God's image ${ }^{7}$ and the commandment to rule over the world, he was granted, is responsible for the world-wide spread of the dualism between man and nature. Thus, the essence of the problem was to be the passage of Gen 1:26-28, particularly the words in Gen 1:28: “[...] and fill

\footnotetext{
${ }^{5}$ See K.J. Kavusa, "Ecological Hermeneutics and the Interpretation of Biblical Texts Yesterday, Today and Onwards: Critical Reflection and Assessment," OTE 32, no. 1 (2019): 229-55.

${ }^{6}$ See L.T. White Jr., "The Historical Roots of Our Ecologic Crisis," Science 155 (1967): 1203-7.

${ }^{7}$ The matter was discussed by a large number of studies. The most recent ones include: D. Simango, "The Meaning of the Imago Dei (Gen 1:26-27) in Genesis 1-11", OTE 25, no. 3 (2012): 638-56; idem, “The Imago Dei (Gen 1:26-27): A History of Interpretation from Philo to the Present", SHE 42, no. 1 (2016): 172-90; J. Jančovič, "Imago Dei: An Exegetical and Theological Reappraisal", ETS -10, no. 2 (2019): 183-206.
} 
the earth and subdue it, and have dominion [...]" ${ }^{8}$ Carl Amery, ${ }^{9}$ Jürgen Moltmann, ${ }^{10}$ and many others shared a similar view. ${ }^{11}$

In light of the accusations levelled against the Bible, it became necessary for theologians and biblical scholars to analyse the issue. Over the past decades, the issues related to ecology in the Bible has been addressed many times and in various ways. As early as in 1977, Norbert Lohfink postulated the necessity to undertake an in-depth reflection on the appropriate interpretation of Gen 1:26-28. ${ }^{12}$ The researchers tried to show that the Bible does not convey such a negative attitude of man towards nature as stated by Lynn $\mathrm{T}$. White Jr. ${ }^{13}$ Sadly, the fact that the natural environment was being devastated not only by the heirs of the Judeo-Christian culture, but also by the followers of other religions, remained unnoticed for a long time in this discussion. The deification of nature cannot serve as a remedy for the ecological crisis. ${ }^{14}$

Over time, a contextual interpretive approach has been developed, known as "ecological hermeneutics", "eco-justice hermeneutics", "environmental hermeneutics," 15 "ecological

\footnotetext{
${ }^{8}$ Bible quotes have been drawn from The Green Bible. New Revised Standard Version, eds. M.G. Maudlin, M. Baer (New York: 2008).

9 See C. Amery, Das Ende der Vorsehung. Die gnadenlosen Folgen des Christentums (Reinbeck: 1972).

${ }^{10}$ See J. Moltmann, God in Creation: An Ecological Doctrine of Creation (London: 1985).

${ }^{11}$ See J.J. Johnson Leese, "Ecofaith: Reading Scripture in an Era of Ecological Crisis," Religions 10, no. 3 (2019): 1-13; R.F. Sadowski, "On Religious and Cultural Principles of Environmental Protection," Problemy Ekorozwoju Problems of Sustainable Development 15, no. 2 (2020): 75-81.

${ }^{12}$ See N. Lohfink, Unsere großen Wörter. Das Alte Testament zu Themen dieser Jahre (Freiburg: 1977), 156-71.

${ }^{13}$ For a detailed description of this issue, see T. Twardziłowski, Ekologiczna hermeneutyka Biblii, 37-41.

${ }^{14}$ See P. de Plunkett, L'écologie de la Bible à nos jours - Pour en finir avec les idées reçues (Paris: 2008), 18-21.

15 The definition of environmental hermeneutics is much broader for it encompasses hermeneutic reflection on the interpretation of all kinds of natural and cultural environments, see, for instance, F. Clingerman, B. Treanor, M. Drenthen, D. Utsler, eds., Interpreting Nature: The Emerging Field of Environmental Hermeneutics (New York: 2014).
} 
reading," or "ecological criticism." 16 The term "hermeneutics" should be understood here as an interpretative approach, although even the precursors of ecological hermeneutics find it difficult to specify the definition of this key concept. ${ }^{17}$

Within the ecological hermeneutics of the Bible, three main currents crystallised: the apologetic, the radical, and the neoorthodox. At this point, a mention is also due to the anti-ecological trend, which is not a scientific reflection. Its supporters postulate unlimited exploitation of natural resources as authorised by the biblical text and willed by God. The latter case in its extreme form rejects the ecological reading of the Bible as the fruit of secularism and the work of Satan. ${ }^{18}$ This kind of reading has a great influence on Christian beliefs and practices among evangelical fundamentalists who, in effect, reject any ecological concerns.

\section{Text, Translation, and Literary Issues}

The analysed verses are part of the account of creation of the world and man (cf. Gen 1:1-2:1). The pericope is of great interest to biblical scholars, who devoted to it a large number of studies. Trying to convey its literary originality, researchers define it, inter alia, as: an account of creation, a story, a narrative, and even a hymn, or simply the creation of the world. As Janusz Lemański writes, this fragment seems to be suspended between poetry and narrative. ${ }^{19}$

In the biblical text, the command given to people has two forms, constituting a frame encompassing the act of creating the man in the

16 See D.G. Horrell, "Ecological criticism," in: Searching for Meaning: An Introduction to Interpreting the New Testament, ed. P. Gooder (London: 2008), 192-8.

${ }^{17}$ See E.M. Conradie, "What on Earth is an Ecological Hermeneutics? Some Broad Parameters," in Ecological Hermeneutics: Biblical, Historical and Theological Perspectives, eds. D.G. Horrell, C. Hunt, C. Southgate, F. Stavrakopoulou (London-New York, 2010), 296-7.

${ }^{18}$ See C. Cumbey, The Hidden Dangers of the Rainbow: The New Age Movement and Our Coming Age of Barbarism (Lafayette: 1983), 162-9.

${ }^{19}$ See J. Lemański, Księga Rodzaju, rozdziały 1-11. Wstęp - przekład z oryginatu - komentarz (NKB. ST 1/1) (Częstochowa: 2013), 138. 
image of God (cf. Gen 1:27). First, these are introduced as God's intention (cf. Gen 1:26), and then presented as an imperative directed to people (cf. Gen 1:28). ${ }^{20}$

\begin{tabular}{|c|c|c|}
\hline Gen 1:26 & Gen 1:27 & Gen 1:28 \\
\hline & & 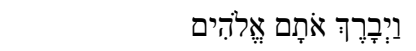 \\
\hline & & God blessed them, \\
\hline 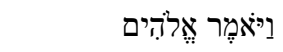 & & וַיאמֶֶר לְֶֶם אֶלהּים \\
\hline Then God said, & & And God said to them: \\
\hline 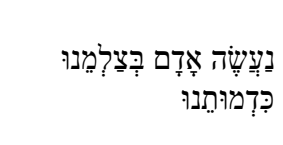 & 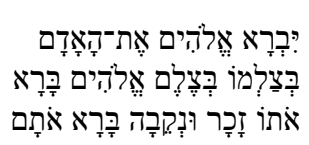 & \\
\hline $\begin{array}{l}\text { "Let us make } \\
\text { humankind }{ }^{21} \text { in } \\
\text { our image, } \\
\text { according to our } \\
\text { likeness; }\end{array}$ & $\begin{array}{l}\text { So God created } \\
\text { humankind in his } \\
\text { image, in the image } \\
\text { of God he created } \\
\text { them }{ }^{22} \text {; male and } \\
\text { female he created } \\
\text { them. }\end{array}$ & \\
\hline & & 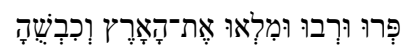 \\
\hline
\end{tabular}

${ }^{20}$ Criticism of the text showed that the analysed fragment is well certified in both Hebrew and Greek manuscripts, and that the text does not require any corrections. The changes observed are in the manuscripts of minor importance; besides, they are not numerous. Most of the changes in Gen 1:28 can be explained by the harmonisation with Gen 1:26, which can be seen especially in the Greek text of the Septuagint.

${ }^{21}$ In the footnotes to The Green Bible with every occurrence of the term humankind an annotation "Heb adam" was made.

${ }^{22}$ The Green Bible adds here in the footnote: „Heb him”. 


\begin{tabular}{|c|c|}
\hline & $\begin{array}{l}\text { "Be fruitful and multiply, } \\
\text { and fill the earth and } \\
\text { subdue it; }\end{array}$ \\
\hline 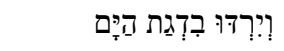 & 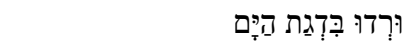 \\
\hline $\begin{array}{l}\text { and let them have } \\
\text { dominion over the } \\
\text { fish of the sea, }\end{array}$ & $\begin{array}{l}\text { and have dominion over the } \\
\text { fish of the sea }\end{array}$ \\
\hline 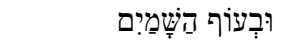 & 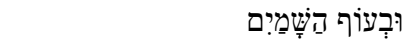 \\
\hline $\begin{array}{l}\text { and over the birds } \\
\text { of the air, }\end{array}$ & and over the birds of the air \\
\hline וּבַבְּהָמָה & \\
\hline \multicolumn{2}{|l|}{ and over the cattle, } \\
\hline 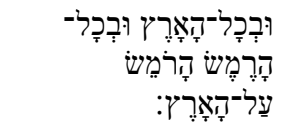 & 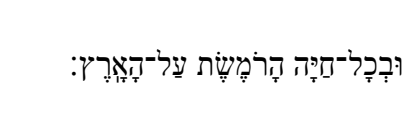 \\
\hline $\begin{array}{l}\text { And over all the } \\
\text { wild animals of the } \\
\text { earth, }{ }^{23} \text { and over } \\
\text { every creeping } \\
\text { thing that creeps } \\
\text { upon the earth." }\end{array}$ & $\begin{array}{l}\text { and over every living thing } \\
\text { that moves upon the earth." }\end{array}$ \\
\hline
\end{tabular}

From the point of view of the ecological hermeneutics of the Bible, the greatest difficulty in this passage is the understanding of two Hebrew verbs: רדָד - "to rule", "to lord over", "to take", "to seize," and - "to subdue", "to have dominion over", "to subjugate", "to violate", "to humiliate", "to force into the

${ }^{23}$ The Green Bible adds here in the footnote: „Syr Heb and over all the earth”. 
humiliation of slavery." 24 It seems rather problematic that the semantic field of these verbs includes power, violence, and military action. Therefore, we will first look at the dictionary meanings of these stems, and their use in the Bible.

The root רדה appears only twenty-seven times in the Hebrew Bible, of which only twice in the Book of Genesis, namely in Gen 1:26.28. Very diverse translations proposed by the Septuagint demonstrate the semantic difficulties associated with this root. ${ }^{25}$ The subject of the verb רָדָ usually has a personal form and pertains to an activity performed by people, either individually or collectively. Also, in most cases individuals or groups of people are the object of this verb. ${ }^{26}$ Only two texts differ in this respect: Joel 4:13, where the object is the wine press, and our Gen 1:26.28, where the earth and the whole animal kingdom are in question. This stem functions in Holy Scripture in a secular context, referring to royal authority, more precisely to the exercise of control over foreign or hostile nations (cf. Pss 110:2; 72:8; Lam 1:13). This results in this stem being frequently associated with the acts of violence, and the motive of anger. Against this background, the text on the evaluation of the conduct of Israel's shepherds (Ezek 34:4) stands out, as it shows that the exercise of power and reign does not have to automatically involve the use of force.

\footnotetext{
${ }^{24}$ It is interesting to note that the NRSV translation in The Green Bible (like many other translations) switches between the meanings of both Hebrew terms. L. Koehler, W. Baumgartner, M.E.J Richardson, J.J. Stamm, The Hebrew and Aramaic Lexicon of the Old Testament, electronic ed., (Leiden-New York: 1999);

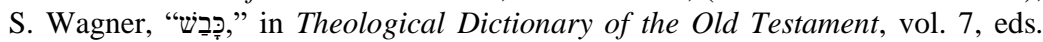
G.J. Botterweck, H. Ringgren, H.J. Fabry (Grand Rapids: 1995), 53-4; H.J. Zobel, "רָָָדָ" in Theological Dictionary of the Old Testament, vol. 13, eds. G.J. Botterweck, H. Ringgren, H.J. Fabry (Grand Rapids: 2004), 330-1.

25 The group of Greek verbs used to translate רָָ includes: ״̌ $\rho \chi \omega$ (cf. Gen 1:26.28;

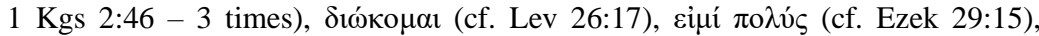

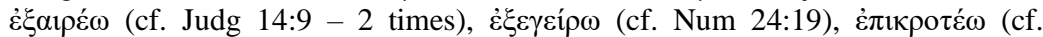

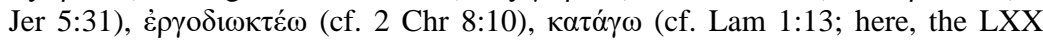

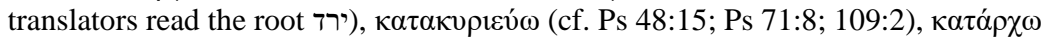

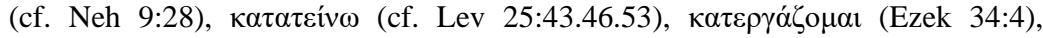

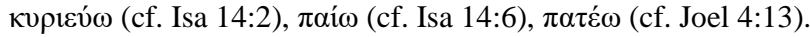

26 See H.J. Zobel, רָדָ, 331.
} 
It seems that the reference for the understanding of the idea of reign introduced by the verb רָדָה is not the context of royal power, but the specific view contained in the narrative context of Gen 1:1-2:3. For it deals with the divine rule over the Earth, and the creatures inhabiting it. This, in turn, involves respecting their distinctiveness as species, and God's order of creation. Here, the author links the reign of men with their having been created in the image and likeness of God (cf. Gen 1:26), concurrently understanding it as a blessing from God (cf. Gen 1:28).

The stem כבש כש occurs only fourteen times in the Old Testament, mostly in the late texts. ${ }^{27}$ The Septuagint renders it with various terms, semantic field of which corresponds to a group of several other Hebrew verbs related to the use of force. ${ }^{28}$ In the case of an action expressed with the verb כָָָּ permitted by God. It appears in several contexts: warfare, when the entire territory along with its population is conquered (Num 32:22-29; Josh 18:1; 1 Chr 22:18); personal, when someone is taken captive (2 Sam 8:11; Jer 34:11.16; $2 \mathrm{Chr} 28: 10$ ), and in relation to sexual violence (Esth 7:8; Neh 5:5). When complemented by the noun - "land," כָרִּץ means "to occupy", "to take possession of something" (cf. Num 32:22-29; Josh 18:1; $1 \mathrm{Chr} 22: 18$ ), and it is rather related to the territorial than the agrarian dimension. The semantic field of this verb also includes the conquest and subordination of the population, as well as the use of the economic and cultural potential related to the idea of land, which has the broadest semantic scope in Gen 1:28, where it refers to the entire habitable area. On the other hand, when the object of כָָּ is man, it takes the meaning "to subdue", "to conquer" (cf. 2 Sam 8:11; Esth 7:8; Jer 34:11).

Therefore, in the case of the verb כָּבָּ occurrence imply the use of some sort of force, and assume the presence of both the weaker and the stronger party. It does not,

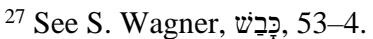

${ }^{28}$ The group of Greek verbs used to translate

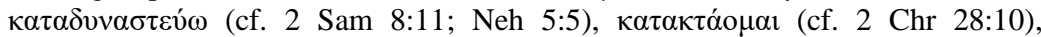

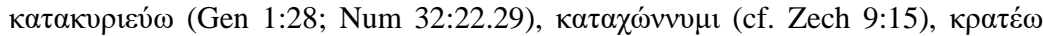
(cf. Josh 18:1), نં Jer 34:16), غ่лıлí $\tau \omega$ (cf. Esth 7:8), $\omega \theta \dot{\varepsilon} \omega$ (cf. Jer 34:11).
} 
however, have to involve violence implicitly. It should be noted that in the context of Gen 1, taking possession of the Earth does not mean taking over an empty territory - for the Earth is already inhabited by beings other than man, since he was the last to be created. Thus, this "taking possession" may involve the conquest of the Earth with greater or lesser effort, and use of force. In Gen 1:28, this verb links the fertility theme in the first part of the verse with the theme of domination in its second section. ${ }^{29}$ Taking possession of land is therefore connected with filling it.

\section{Genesis 1:26-28 within the Apologetic Current in Ecological Hermeneutics}

In the opinion of the supporters of the apologetic trend, also known as apologetic hermeneutics, or hermeneutics of recovery, the biblical text of Gen 1:26-28 is in itself environmentally friendly from the ecological point of view. According to Richard Bauckham, the positive vision of man as a responsible governor is inextricably linked with the biblical text, the interpretation of which was only distorted in the Renaissance, on the wave of humanists' fascination with Greek philosophical thought - and even more so in the era of the Enlightenment. ${ }^{30}$ In an ecological discussion, one should strive to show the value of the inspired text, and to recover its original meaning, which has been distorted in the tradition of interpretation.

Similar conclusions were drawn by Norbert Lohfink, who opposed the separation of Gen 1:28 from the context of the entire account of creation, and the omission of its historical and cultural context. ${ }^{31}$ It should be taken into consideration that like a constant refrain recurring throughout the narrative, long before man was created, the creation is evaluated positively in God's eyes as טוֹ טוב "good" (cf. Gen 1:4.10.12.18.21.25), and ultimately as טמאד טוֹ "very good" (cf. Gen 1:31). Thus, everything that God created was

\footnotetext{
${ }^{29}$ See Z. Pawłowski, Opowiadanie Bóg i początek. Teologia narracyjna Rdz 1-3 (RSB 13) (Warszawa: 2003), 340.

${ }^{30}$ See R. Bauckham, God and the Crisis of Freedom: Biblical and Contemporary Perspectives (Louisville: 2002), 141.

${ }^{31}$ See N. Lohfink, Unsere großen Wörter, 156-71.
} 
a value in itself, not merely in the service of man. According to Gen 1 , God assessed it that way before man was created. According to the inspired author, the entire work of creation, viewed as a harmonious whole, was referred to with the adverb "very." This is all the more important because in the neighbouring cosmogonies known to the Israelites, the matter of creating the world and man tends to be evil, demonic, and, in general, overwhelmingly horrific, furthermore requiring some force to keep it in check. ${ }^{32}$ On the other hand, it should also be remembered that the image in Gen 2, presenting a different sequence of creation, justifies the existence of living creatures by their ability to help man (cf. Gen 2:18). The Book of Genesis, above all, in its cultural context brings a new view of the nature of the world, and of man who, having originated from the good God, is himself good, orderly, and beautiful.

According to Gabriel Witaszek, "the ecological task of the Book of Genesis" 33 is to be expressed in this concept with the Hebrew verbs describing (Gen 1-2) the relationship between man and creation: רָדָדה - "to rule" (cf. Gen 1:26.28), "to occupy", "to take possession" (cf. Gen 1:28), עָבָרָ - "to cultivate" (cf. Gen 2:5.15), and שָָָׁ - "to look after", "to guard" (cf. Gen 2:15). The proposed understanding of the verb רִָ focuses in this interpretation on responsible, non-violent management. Such an understanding of this stem occurs, for example, in Ezek 34:4, where the prophet presents the rulers of Israel as shepherds filled with violence and cruelty, instead of care and compassion. ${ }^{34}$ According to Norbert Lohfink, translating the verb רָדָ as "to accompany", "to graze", "to lead," and "to command" corresponds to an ancient thought combining the idea of a ruler with that of a shepherd. ${ }^{35}$ Gabriel Witaszek states that this does not mean destruction, but preservation, protection, and the use not as much according to needs as according to the nature and forces of the created beings. ${ }^{36}$ The reign over other creatures is specifically understood here as the right

\footnotetext{
${ }^{32}$ See P. de Plunkett, L'écologie de la Bible à nos jours, 24-6.

${ }^{33}$ See G. Witaszek, "Kościół wobec ekologii,” ZN KUL 36, nos. 141-4 (1993): 46.

${ }^{34}$ See R. Bauckham, Bible and Ecology. Rediscovering the Community of Creation (London: 2010), 18.

${ }^{35}$ See N. Lohfink, Unsere großen Wörter, 166.

${ }^{36} \mathrm{G}$. Witaszek, Kościół wobec ekologii, 44-5.
} 
to tame animals, ${ }^{37}$ and use them for labour. ${ }^{38}$ This thesis even remained unhindered by the fact that the catalog did not include a divine command regarding flock and cattle. The fully positive image of a human being is complemented by the reference to the idea of a shepherd taking care of the herd. ${ }^{39}$ Man's superiority over other creatures reveals his likeness to God, so it would be an empathetic and caring power, not a dominant and exploitative one. The distortion of this original, valuable message resulted in an anthropocentric interpretation, justifying the selfish use of nature by man for his own purposes.

The reign over creation is justified by the verses preceding the command given to man. God's special commitment is indicated by the quotation of his reflection in the direct speech in the form of the volitive plural jussive: נַעְשֶׁה - "let us make humankind" (cf. Gen 1:26). The exceptional role of man in God's creative plan is emphasised by the narrator's further comment - the image and likeness of God (cf. Gen 1:27) give man a special position among other creatures. However, he does not remain separate from the world, ${ }^{40}$ but inhabits it and cares for it as his living environment.

An important role in this argument is played by the reference to the authority of the seniority of the so-called Yahwist narrative in Gen 2, in which God commands man to עָברָ - "cultivate/till" the garden of Eden and שֵֵַָׁ - "to guard / keep it" (cf. Gen 2:15), which is undoubtedly positive in its tone. Adam, like other creatures moulded from the dust of the earth, receives the special privilege of naming animals, which means seizing a power over them (cf. Gen 2:7.19-20). God made man the custodian of the creation; therefore, his task is to protect and be responsible for the earth, to remain in a close relationship with it, to cultivate it and eat its fruits. ${ }^{41}$ Man was blessed to be fertile and fill the earth, just as sea creatures and

\footnotetext{
${ }^{37}$ See A.J. Najda, "Początki ekologii w Biblii," SEB 2 (2004): 146-8.

${ }^{38}$ Ibid., 145; J. Suchy, "Czyńcie sobie ziemię poddaną, panujcie nad zwierzętami," ZN KUL 36, nos. 141-4 (1993): 14.

${ }^{39}$ Cf. J. Suchy, "Ekologiczne przesłanie Biblii," in Social life in the Bible, ed. G. Witaszek (Lublin: 1997), 178-9.

${ }^{40}$ See G. Witaszek, Kościół wobec ekologii, 44; J. Suchy, Ekologiczne przesłanie Biblii, 176.

${ }^{41}$ See R. Bauckham, Bible and Ecology, 22.
} 
birds were blessed with regard to their respective environments of living. The command to rule over the creation should be perceived from the angle of the herbivorousness of the first humans, instead of being associated with killing, or carnivorousness. ${ }^{42}$ As a result of this extraordinary relationship between man and the rest of the creation, the consequences of the sin of the first humans will also affect the earth (cf. Gen 3:17-19), and only with time will animals begin to fear humans, who will start killing them for food (cf. Gen $9: 2-3)$.

\section{Genesis 1:26-28 within the Radical Current in Ecological Hermeneutics}

According to the supporters of the radical hermeneutics current, referring to the hermeneutics of suspicion and resistance, the problem lies in the biblical texts themselves, which lean toward anthropocentrism, and thus do not take into account the perspective of the entire ecosystem, of which non-human beings are equal members. ${ }^{43}$

The suspicion of the anthropocentric orientation in the account of creation, according to the adherents of the above-mentioned thesis, finds its confirmation in the biblical text. It can be seen when the rhythm of the description of the creation is disturbed (initially the Earth is God's partner in creation, and all creatures are equal), and attention is shifted to showing the privileged position of humans in the relationship with God (they were the only ones created in the image and likeness of God, and are mandated to rule over all of the creation). The narrative justifying the special status of man and providing the theological foundations for his reign over nature introduces a chasm between him and the rest of the created world,

\footnotetext{
${ }^{42}$ See J. Suchy, Ekologiczne przestanie Biblii, 179.

43 See N.C. Habel, "Introducing Ecological Hermeneutics," in Exploring Ecological Hermeneutics (SBL.SympS 46), eds. N.C. Habel, P. Trudinger (Atlanta: 2008), 3; "Introducing The Earth Bible Commentary Series," in The Birth the Curse and the Greening of Earth. An Ecological Reading of Genesis 1-11 (EBC 1) (Sheffield: 2011), 8; "Introducing The Earth Bible Commentary Series," in: Finding Wisdom in Nature. An Eco-Wisdom Reading of the Book of Job (EBC 4) (Sheffield: 2014), 4.
} 
which is displayed by the exploitation and injustice of mankind towards the Earth. ${ }^{44}$ The analysed fragment may be shown in a new light thanks to the identification of the reader with non-human beings, which, as characters, were left unmentioned in the text. The identification procedure is complemented by the retrieval of the voice of the entire earthly community in the narrative.

The representatives of this current emphasise that a careful analysis of the creation story in Gen 1 demonstrates that the Earth plays an important role in it. As one of the characters, it is introduced in Gen 1:1-2, where in the primordial waters it awaits its birth geophany, ${ }^{45}$ on the third day of creation. From that moment on, it becomes the subject of action, and God's partner in the work of creation. Therefore, its role as the mother who gives birth to everything that exists cannot be underestimated. The suppression of its positive image in Gen 1:25-28 becomes all the more incomprehensible. Postulated as a remedy for this state of affairs is the deconstruction of text, one that would not depreciate or marginalise the role of nature, and its subsequent reconstruction. Its aim is to creatively develop new versions of the texts, taking into account the perspective of the entire earthly community, as was intended in the framework of The Earth Bible Project, an international and interfaith group of scientists led by Norman C. Habel. Their guidelines consist, firstly, in the suspicion of anthropocentrism of a given text; secondly, in identification with the Earth and non-human beings; and finally in the retrieval of the perspective or voice of the Earth, previously suppressed by anthropocentric perspective in the text. Such a reconstruction of the biblical text was proposed, for instance, by Norman C. Habel. ${ }^{46}$

\footnotetext{
${ }^{44}$ See N.C. Habel, The Birth, the Curse and the Greening of Earth, 37-8.

${ }^{45}$ See N.C. Habel, "Geophany: The Earth Story in Genesis One," in The Earth Story in Genesis (EB 2), eds. N.C. Habel, S. Wurst (Sheffield: 2000), 34-48.

${ }^{46}$ N.C. Habel presented the results of his research in the paper "Playing God or Playing Earth? An Ecological Reading of Genesis 1:26-28," delivered on November 20, 2005 at the 2005 SBL Annual Meeting in Philadelphia (Session S20-113). The text was then published: N.C. Habel, "«Playing God or Playing Earth?»: An Ecological Reading of Genesis 1:26-28," in “And God Saw That It Was Good." Essays on Creation and God in Honor of Terence E. Fretheim
} 
For creatures, the consequences of the blessing given to humans are particularly fateful. By the divine mandate, mankind is to כָּבָּ "subdue," "trample," and רָדָה - "rule." According to the supporters of the radical form of ecological hermeneutics, the same verbs which in the apologetic current determined the ecological task arising from this pericope, are a flashpoint of discussion and a problem that cannot be ignored. In their opinion, it is impossible to pass over the aggressive and negative connotation of these verbs. ${ }^{47}$ It was not disregarded by the anthropocentric editors of the Book of Genesis. The purpose of the narrative was to show the unique relationship of man with God, and the resulting special position of humankind towards creatures, and to confirm that violence and exploitation were inscribed in it from the very beginning of the world.

\section{Genesis 1:26-28 within the Neo-orthodox Current in Ecological Hermeneutics}

Representatives of the neo-orthodox current appreciate the efforts made by the supporters of the deconstructive and reconstructive current, intended to purify the message of the Bible. On the other hand, they negatively assess their appropriation of biblical texts, and the devaluation of centuries of the Judeo-Christian tradition that is too rich to be seen only in light or dark colours. They also warn against treating the story of creation as a faithful description of events. ${ }^{48}$ Instead, they propose a revisionist hermeneutics approach, consisting in revision and ecologically critical reading of both the pericopes, and the interpretative traditions related to them.

(WWSup 5), eds. F. Gaiser, M. Throntveit (Saint Paul: 2006), 33-41. Three years later, he presented a more elaborate version of this reconstruction: N.C. Habel, The Birth, the Curse and the Greening of Earth, 44-5.

${ }^{47}$ See N.C. Habel, "Playing God or Playing Earth?," 39; J. Lemański, Księga Rodzaju, rozdziaty 1-11, 172.

48 See J.W. Rogerson, "The Creation Stories: Their Ecological Potential and Problems," in Ecological Hermeneutics: Biblical, Historical and Theological Perspectives, eds. D.G. Horrell, C. Hunt, C. Southgate, F. Stavrakopoulou (London-New York: 2010), 27. 
Revisionists point out the necessity to interpret the passage in Gen 1:26-28 with reference not only to the entire pericope of Gen $1: 1-2: 3$, but also to its place in the narrative structure of Gen 1-9. Before man existed, the conditions for his existence had been created. However, their role should not be limited to constituting the living environment for man, who is complementarily linked to the entire creative work of God. The Earth actively participates in this process, already in Genesis 1:11 acquiring the status of a subject. In the first five days of creation, the Earth appears in the narrative as an active participant in the creation process, ${ }^{49}$ individual acts of which are initiated and then approved by God, as reported by the

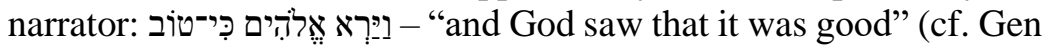
$1: 4.10 .12 .18 .21 .25) .{ }^{50}$ The supreme goal of all creation is the worship of God, which is expressed by the establishment of the Shabbat on the seventh day (cf. Gen 2:2-3).

In the subsequent verses (cf. Gen 1:29-30), the impassable boundary that determines the harmony of created beings is defined. Living creatures - both humans and animals-have to be herbivores. Emphasising this aspect clearly weakens that of aggression, ferocity, and carnivorousness assumed in the verbs רָָּ and

Reign over nature, mandated by God, has its limits, which the inspired authors repeatedly recall in the pages of the Holy Scripture, clarifying the intuitions presented in Gen 1:1-2:3. For man was not appointed the lord of all creation, but rather its administrator, whose duty is to respect the laws given by the Creator. This was also noticed by medieval commentators who interpreted this narrative as an incentive to create equilibrium and harmony among created beings. Excessive exploitation of nature, occurring against the original order, was understood as the result of disorder caused by the

\footnotetext{
${ }^{49}$ See Z. Pawłowski, Opowiadanie Bóg i początek, 314.

${ }^{50}$ See W.P. Brown, Structure, Role, and Ideology in the Hebrew and Greek Texts of Genesis 1:1-2:3 (Atlanta: 1993), 95-100. It is worth noting the fact that although the Hebrew construction does not have any verb here, most modern translations use the past tense ("it was"), assuming that the creation might have ceased to be good, e.g., due to the original sin of the first people. This is an example of an overinterpretation in translation that has serious doctrinal repercussions.
} 
human $\sin .{ }^{51}$ It was sin that caused the gradual degeneration of mankind and the fall of all creation. This is shown in the subsequent chapters of Genesis, and culminates in the section Gen 6-9, about Noah and the Flood. Enmity between the world of humans and the world of animals, and killing them for food emerges only after the Flood (cf. Gen 9:1-7), when God, renewing his blessing over people, at the same time gives Noah's sons permission to eat animals. The concentric structure of the narrative in Gen 1-9 $9^{52}$ emphasises the discrepancy between God's plan and its fulfilment by man, or as a matter of fact the failure thereof. The Flood is the reversal of the creative process, and the beginning of a new order. In this context, it appears as God's judgment on creation, and the forces of nature, especially the water coming from heaven become the executors of God's verdict. ${ }^{53}$ The extent of the Flood is limited to the Earth fauna. The cataclysm does not affect the sea and its inhabitants, nor the Earth, which remains fertile and produces flora immediately after the Flood ceases (cf. Gen 8:11); the order in heaven is not disturbed either. Time and seasons remain unshaken. God is committed to saving the righteous, and the representatives of all species, leading the rescue operation and personally closing the doors of the ark (cf. Gen 7:16).

The survivors, contaminated with sin, bring it into the renewed world. It is therefore a world of compromise in which God leaves room not only for human freedom as before, but also for human weakness. In another blessing God extends the man's authority (cf. Gen 9:1-3). From then on, other creatures fear him and are destined to be his food. However, drinking their blood is still strictly prohibited as an impassable boundary (cf. Gen 9:4). After renewing the mandate to rule over creation (cf. Gen 9:7), God makes a covenant not only with Noah and his family, but also with all of the creation (cf. Gen 9:9-10).

\footnotetext{
${ }^{51}$ See G. Ovitt, The Restoration of Perfection: Labor and Technology in Medieval Culture (London: 1987), 70-85.

${ }^{52}$ See Lemański, Księga Rodzaju, rozdziały 1-11, 28-31.

53 The image of the destructive power of water is found in many places in the Bible, for instance, in Pss 18:16; 65:5-8; 89:10; 93:3-4; Dan 9:26.
} 
Supporters of the neo-orthodox current claim that the fragment of Gen 1:26-28 read in the context of Gen 1-9 does not motivate, let alone allow, any excessive or arbitrary exploitation of the world by humans, but constitutes a criticism of human behaviour towards creation, and of the evil which lies at its foundation. In their opinion, God's command in Genesis 1:26-28-for man to rule over creation - has a prophetic character and appears as an ideal that should be pursued.$^{54}$ It is an invitation to create a community capable of living in the world according to God's intention.

The reference to the entire biblical canon is not without significance here, as the theme of human care for creation is also taken up by other inspired authors of the Old Testament (e.g., Deut 5:12-16; Prov 1:10; Hos 2:20). In the New Testament, this value is emphasised even more clearly. The mission of Jesus had a special role here. The practice of animal sacrifice has been permanently and effectively replaced by Christ's only sacrifice on the cross (cf. Heb 10:1-18). This is the key to making a world consistent with God's intentions, not only in the eschatological dimension, but also here on Earth. In the opinion of revisionists, only such an interpretation reflects the intentions of the editors of the inspired text, which is not a scientific argument, but a myth, understood as a story about the origin of the surrounding world, the harmony of which has been disturbed by the disobedience of the first parents, and the repercussions of this offence are painfully experienced up to our times, not only by humans. ${ }^{55}$

The contemporary ecological crisis is a complex and multilayered phenomenon. It should be acknowledged that physical ecology is inextricably linked with human ecology, ${ }^{56}$ and cannot be

\footnotetext{
${ }^{54}$ See J.W. Rogerson, The Creation Stories, 26.

55 Ibid. 7; also J. Lemański, Księga Rodzaju, rozdziały 1-11, 137; Z. Pawłowski, Narracja i egzystencja. Genesis $w$ hermeneutyce opowieści (STTh 29) (Toruń: 2013), 99.

${ }^{56}$ P. de Plunkett, L'écologie de la Bible à nos jours, 161.
} 
considered separately, because man and the environment undeniably and constantly interact with each other.

The first and most important perspective that emerges from the biblical narrative is the perception of the natural environment as a creation, that is as having its beginning and end in the creative act of the Only God. This is a basic pre-understanding that should be kept in mind when studying the text in order to achieve understanding. It is also a certain horizon of understanding for all other issues arising from the biblical text. The story of creation should be treated as a whole in Gen 1-2, consisting of two complementary episodes presenting the same narrative event from different perspectives: Genesis 1:1-2:3 contains a broader view covering the entire created world, while Genesis 2:4-3:24 takes a narrower perspective, presenting the world from the standpoint of man and his relationship to the world, and the Creator. In the biblical narrative of creation, it was clearly emphasised that the Earth was created before man and that God gave it to him as a gift, at the same time marking the limits of his authority. Moreover, the Earth, being an organic whole, has its own genealogy (Genesis 2:4). ${ }^{57}$ It is the case that the biblical text is not biocentric, as would be desired by the supporters of a radical form of ecological hermeneutics. However, it is worth noting here that, contrary to their belief, it is not solely anthropocentric, but also theocentric. Man is not an end in himself. The Judeo-Christian tradition links the act of creation with God's plan of love, in which the existence of every being is inscribed with the indispensable inner value of being God's work. ${ }^{58}$ In terms of ecological hermeneutics (regardless of its current), the unique status of man does not entitle him to any or excessive exploitation of the natural environment, but obliges him to look at this work in accordance with the perspective of God and to recognise that other creatures are valuable to Him in themselves and that a man himself is also a creature. The purpose of the biblical narrative is not to describe the world in order to understand how it can be exploited, but to speak about it in such a way that it can be

57 J. Lemański, “Genealogie Rdz 1-11,” CT 83, no. 34 (2013): 12-14.

58 See J.H. Sherman, "Reading the Book of Nature after Nature," Religions 11, no. 4 (2020): 9-10. 
viewed as God's work. The existence of the world is not a coincidence or a side effect of other actions taken by deities, as suggested by the mythologies of neighbouring peoples ${ }^{59}$ at the time of writing the text of the Bible, but it results from a free decision of God. All creatures - as His works - reflect a ray of God's wisdom and goodness. ${ }^{60}$

Achieving the state intended by God depends on the quality of the relationship between man, nature, and animals, based on the paradigm of service, and not that of exploitation. In the story of creation, man was not established the sole and autonomous ruler of the Earth. The attempt at such self-perception, proposed to man by the serpent in Gen 3, led to the abandonment of the Garden of Eden. The command to subdue the Earth results from the dignity bestowed upon man by creating him in the image and likeness of God; therefore, it presupposes that man should act in accordance with God's plan and within the framework of the laws given by the Creator. This task of man must be rediscovered. ${ }^{61}$ The very narrative of the creation in the Book of Genesis appears to be an invitation to build a community of creatures in accordance with the Creator's plan, the realisation of which is possible thanks to cooperation with God's grace.

The quoted positions clearly show that interpreting the command (Gen 1:26-28) — ordering man to rule over the Earth-in a hermeneutic key, taking into account the circumstances of the creation and the specificity of the biblical text, does not mean justification for the degradation of the natural environment or giving up the use of natural resources. The thesis raised these days with particular intensity that everything that is technically possible is good and should be allowed is false. It is also necessary for the actions taken by a person to comply with ethical standards, taking God's law into consideration. Also, contrary to previous claims, we already know today that natural resources are not inexhaustible, and

\footnotetext{
${ }^{59}$ See J. Lemański, Księga Rodzaju, rozdziały 1-11, 122-31.

${ }^{60}$ See "Catechism of the Catholic Church," No. 339, accessed September 30, 2020, http://www.vatican.va/archive/ENG0015/_INDEX.HTM.

${ }^{61}$ See E.M. Conradie, "The Four Tasks of Christian Ecotheology: Revisiting the Current Debate," Scriptura 119, no. 1 (2020): 1-13.
} 
that technology will not replace the biodiversity, and the deposits of raw materials on Earth.

The answer to the socio-ecological crisis must be the constant practice, and the development of human sensitivity to the value of creation. Controlling the forces of nature in harmony with the entire community of the Earth is not only possible, but also necessary, and it requires the development of a new position. ${ }^{62}$ It intends the rational use of natural resources and the reduction of pollution. For this purpose, renewable energy sources should be used, such as sunbeams, wind, rainfall, flowing water, or geothermal energy. These methods have been known to mankind for centuries, they can still be improved and changed in accordance with the current state of knowledge. The aim is to use biodiversity in such a way that does not cause significant damage to the environment, without which man would not be able to survive. However, overcoming the myth of the infinite progress and the consumerism developed in economics ${ }^{63}$ requires a Christian commitment and concern to preserve God's work and not use it beyond what is necessary for existence. Exercising the virtue of moderation and not yielding to artificially created needs of continuous consumption plays a key role here.

\section{Bibliography}

Amery C., Das Ende der Vorsehung. Die gnadenlosen Folgen des Christentums, Reinbeck 1972.

Bauckham R., Bible and Ecology. Rediscovering the Community of Creation, London 2010.

Bauckham R., God and the Crisis of Freedom: Biblical and Contemporary Perspectives, Louisville 2002.

Brown W.P., Structure, Role, and Ideology in the Hebrew and Greek Texts of Genesis 1:1-2:3, Atlanta 1993.

Catechism of the Catholic Church, accessed September 30, 2020, http://www.vatican.va/archive/ENG0015/_INDEX.HTM.

${ }^{62}$ An extensive study can serve as an example here: T\&T Clark Handbook of Christian Theology and Climate Change, eds. H.P. Koster, E.M. Conradie (London-New York: 2019).

${ }^{63}$ See P. de Plunkett, L'écologie de la Bible à nos jours, 145-6. 
Conradie E.M., "The Four Tasks of Christian Ecotheology: Revisiting the Current Debate," Scriptura 119, no. 1 (2020): 1-13.

Conradie E.M., "What on Earth is an Ecological Hermeneutics? Some Broad Parameters," in Ecological Hermeneutics: Biblical, Historical and Theological Perspectives, eds. D.G. Horrell, C. Hunt, C. Southgate, F. Stavrakopoulou, London, New York, 2010, 296-7.

The Creation of Man and Woman: Interpretations of the Biblical Narratives in Jewish and Christian Traditions (TBN 3), ed. Luttikhuizen G.P., Leiden, Boston, Köln 2000.

Cumbey C., The Hidden Dangers of the Rainbow: The New Age Movement and Our Coming Age of Barbarism, Lafayette 1983.

Francis, "Encyclical Laudato si"," (May 24, 2015), no. 67; English translation, accessed September 30, 2020, http://www.vatican.va/ content/dam/francesco/pdf/encyclicals/documents/papa-francesco_20 150524_enciclica-laudato-si_en.pdf.

The Green Bible. New Revised Standard Version, eds. M.G. Maudlin, M. Baer, New York 2008.

Habel N.C., "«Playing God or Playing Earth?»: An Ecological Reading of Genesis 1:26-28," in "And God Saw That It Was Good." Essays on Creation and God in Honor of Terence E. Fretheim (WWSup 5), eds. F. Gaiser, M. Throntveit (Saint Paul: 2006), 33-41.

Habel N.C., Finding Wisdom in Nature. An Eco-Wisdom Reading of the Book of Job (Earth Bible Commentary 4), Sheffield 2014.

Habel N.C., "Geophany: The Earth Story in Genesis One," in The Earth Story in Genesis (EB 2), eds. N.C. Habel, S. Wurst (Sheffield: 2000), $34-48$.

Habel N.C., "Introducing Ecological Hermeneutics," in Exploring Ecological Hermeneutics (SBL.SympS 46), eds. N.C. Habel, P. Trudinger, Atlanta 2008, 1-8.

Habel N.C., The Birth the Curse and the Greening of Earth. An Ecological Reading of Genesis 1-11 (Earth Bible Commentary 1), Sheffield 2011.

Harrisson P., "Subduing the Earth: Genesis 1, Early Modern Science, and the Exploitation of Nature," JR 79, no. 1 (1999): 86-109.

Horrell D.G., "Ecological criticism," in: Searching for Meaning: An Introduction to Interpreting the New Testament, ed. P. Gooder, London 2008, 192-8.

Interpreting Nature: The Emerging Field of Environmental Hermeneutics, eds. F. Clingerman, B. Treanor, M. Drenthen, D. Utsler, New York 2014.

Jančovič J., "Imago Dei: An Exegetical and Theological Reappraisal”, ETS 10, no. 2 (2019): 183-206. 
Johnson Leese J. J., "Ecofaith: Reading Scripture in an Era of Ecological Crisis," Religions 10, no. 3 (2019): 1-13.

Kavusa K.J., "Ecological Hermeneutics and the Interpretation of Biblical Texts Yesterday, Today and Onwards: Critical Reflection and Assessment," OTE 32, no. 1 (2019): 229-55.

Koehler L., Baumgartner W., Richardson M.E.J, Stamm J.J., The Hebrew and Aramaic Lexicon of the Old Testament, electronic ed., Leiden, New York 1999.

Lemański J., "Genealogie Rdz 1-11”, Collectanea Theologica 83 (2013) no. 4: 12-14.

Lemański J., Księga Rodzaju, rozdziały 1-11. Wstęp-przekład z oryginatu - komentarz (NKB. ST 1/1), Częstochowa 2013.

Lohfink N., Unsere großen Wörter. Das Alte Testament zu Themen dieser Jahre, Freiburg 1977.

Moltmann J., God in Creation: An Ecological Doctrine of Creation, London 1985.

Najda A.J., "Początki ekologii w Biblii," SEB 2 (2004): 146-8.

Out of Paradise: Eve and Adam and Their Interpreters (Hebrew Bible Monographs 30), eds. B. Becking, S. Hennecke, Sheffield 2011.

Ovitt G., The Restoration of Perfection: Labor and Technology in Medieval Culture, London 1987.

Pawłowski Z., Narracja i egzystencja. Genesis w hermeneutyce opowieści (Scripta Theologica Thoruniensia 29), Toruń 2013.

Pawłowski Z., Opowiadanie Bóg i początek. Teologia narracyjna Rdz 1-3 (Rozprawy i Studia Biblijne 13), Warszawa 2003.

Plunkett P. de, L'écologie de la Bible à nos jours - Pour en finir avec les idées reçues, Paris 2008.

Re-interpretations of Genesis I in the Context of Judaism, Ancient Philosophy, Christianity, and Modern Physics (Themes in Biblical Narrative 8), eds. G.H. van Kooten, Leiden, Boston 2005.

Rogerson J.W., "The Creation Stories: Their Ecological Potential and Problems," in Ecological Hermeneutics: Biblical, Historical and Theological Perspectives, eds. D.G. Horrell, C. Hunt, C. Southgate, F. Stavrakopoulou, London, New York 2010.

Sadowski R.F., "On Religious and Cultural Principles of Environmental Protection," Problemy Ekorozwoju - Problems of Sustainable Development 15, no. 2 (2020): 75-81.

Sherman J.H., "Reading the Book of Nature after Nature," Religions 11, no. 4 (2020): 9-10.

Simango D., "The Imago Dei (Gen 1:26-27): A History of Interpretation from Philo to the Present", SHE 42, no. 1 (2016): 172-90. 
Simango D., "The Meaning of the Imago Dei (Gen 1:26-27) in Genesis 1-11", OTE 25, no. 3 (2012): 638-56.

Suchy J., "Czyńcie sobie ziemię poddaną, panujcie nad zwierzętami," ZN KUL 36, nos. 141-4 (1993): 13-23.

Suchy J., "Ekologiczne przesłanie Biblii," in Social life in the Bible, ed. G. Witaszek, Lublin 1997.

T\&T Clark Handbook of Christian Theology and Climate Change, eds. H.P. Koster, E.M. Conradie, London, New York 2019.

Twardziłowski T., Ekologiczna hermeneutyka Biblii, Warszawa 2015.

Twardziłowski T., Ocalić stworzenie. Teoria i zastosowanie ekologicznej hermeneutyki Biblii, Warszawa 2017.

Wagner S., "כָּבָּשָ" in Theological Dictionary of the Old Testament, vol. 7, eds. G.J. Botterweck, H. Ringgren, H.J. Fabry, Grand Rapids 1995, $52-7$.

White L.T. Jr., "The Historical Roots of Our Ecologic Crisis," Science 155 (1967): 1203-7.

Witaszek G., "Kościół wobec ekologii,” ZN KUL 36, nos. 141-4 (1993): 43-56.

Wöhrle J., "Dominium terrae: Exegetische und religionsgeschichtliche Überlegungen zum Herrschaftsauftrag in Gen 1, 26-28," ZAW 121, no. 2 (2009): 171-88.

Zobel H.J., "רָדזה," in Theological Dictionary of the Old Testament, vol. 13, eds. G.J. Botterweck, H. Ringgren, H.J. Fabry, Grand Rapids 2004, $330-6$. 